\title{
Analysing labels, associations, and sentiments in Twitter on the Abu Sayyaf kidnapping of Viktor Okonek
}

\begin{abstract}
This paper investigates Twitter data related to the kidnapping case of two German nationals in the southern region of the Philippines by the Abu Sayyaf Group (ASG). It explores perceptions of the ASG, along with associated organizations and sentiments indicated in the tweets together with statistically significant relationships. Findings revealed that: "Rebel" and "Militant" were the most frequently used labels for the ASG; Majority of the tweets contained sentiments that assess threats such as abduction and kidnapping of hostages; and almost half contained words that indicate negotiation or concession to the demands of the captors. Logistic regression analyses on "Rebel" and "Islamist" revealed positive coefficients for these sentiments used as predictors. This meant that people who assessed threats and expressed sentiments that responses should concede to the captors' demands were more likely to use the "Rebel" or "Islamist" labels. Rather than the two longstanding dominant narratives of the ASG as terrorist and criminals, the emerging rebel and militant labels, suggest a more domestically and politically sensitive Twitter commentarial than represented in the work of the Al-Qaeda centric paradigm exponents. These findings along with the complex associated political and policy contexts and implications are discussed in this paper.
\end{abstract}

Keywords: Abu Sayyaf, Islamist, Militant, Mindanao, Rebel, Kidnapping, Terrorism

\section{Introduction}

According to the popular award winning American author/journalist Mark Bowden, Mindanao and the ASG are very much 'jihadists in Paradise'. Such high profile attention (primarily off the back of the 2001 'Dos Palmas Kidnappings' of Martin and Gracia Burnham (and others) by the ASG) has lead to a well-established, and little contested, focus of US foreign policy around 'fighting them there, so we don't have to fight them here'2. Diplomatically the Philippines stood shoulder to shoulder ${ }^{3}$ with the US following 9/11 and demonstrated this by promising to take on the ASG ${ }^{4}$. Making Mindanao the poster-boy for the second front thesis 5 , portraying it as the go-to sanctuary in the region for the jihad. While a precious minority has advocated caution and problems, a "dominant model, perpetuated in the media by prominent commentators Rohan Gunaratna and Zachary Abuza"6, have established an influential predilection for what Carlyle Thayer called the "al Qaeda-centric paradigm"7.

The Abu Sayyaf Group is one of many, but perhaps the most telling of enigmas in the Muslim insurgency in Mindanao. Levels of understanding on who, what, and why they are is perhaps illustrated best and most recently through social media - where such (mis)understandings proliferate, complicate and cement. The Okonek kidnapping offers us a contemporary case to analyse how traditional media previously misled the public, often through reliance on questionable academic work, against contemporary views in new media $^{8}$ on the ASG. The labels, associations, and sentiments directed towards the ASG elucidate the level and complexity of public understanding on one of the most contentious and important aspect of one of the world's longest running conflicts. The ASG have come 
to represent the international terror dimension to what until 9/11 was regarded as largely an indigenous insurgency. The 'popular representations' 9 in the media of the ASG have, as Ugarte has shown, come from a reliance on official reports, resulting in propaganda. This research was undertaken because we "realize that claims have consequences" 10 and many claims are made of the ASG, this would be an opportune moment to measure those consequences.

"The phrase "al-Qaeda-linked" has become a permanent, self-perpetuating fixture that is questioned by no one and repeated by everyone."11

Supposedly the region is "afflicted" 12 by an ideological menace that has "shifted from the middle east to the Asia-pacific region"13. This supposed Talibanzation of Southeast Asia as Bilveer Singh would have us believe, has created a widespread and entrenched postulation that the jihad is connected, conspiratorially organised and controlled, with the ASG the lethal tip of the tentacle. Mindanao was therefore said to be 'the next Afghanistan'14 because of the ASG. The prominent rationale for the preoccupation to the idea that Southeast Asia and Mindanao in particular is 'connected' is through a process known as radicalisation, and the idea of failed states becoming a 'sanctuary' or 'breeding ground' for the jihad ${ }^{15}$ by the spread of radicalization. Like a pathogen spread top-down from the ASG's "charismatic leaders"16 Mindanao became cast by way of little more than second hand unverifiable stories:

"Osama personally forged the link with Abdurajak Janjalani, the founder and leader of ASG. ASG'S organization, ideology, target selection and tactics are deeply influenced by Al Qaeda... The extent of the Al-Qaeda-Philippines link was such that by integrating a few hundred Moros from Mindanao, in the southern Philippines, first to wage jihad and thereafter to secure Al Qaeda's assistance in their fight for an independent Islamic state, it established a special Moro sub-brigade in Afghanistan. ${ }^{17}$

Academic understanding is caught between Thayers "radically different view"18 and the dangerous 'pathologizing' of the jihad, common in the radicalisation explanation, as Hamilton-Hart brilliantly recognized ${ }^{19}$. The armies of Overseas Filipino Workers (OFWs) in the Middle East and elsewhere, who come and go routinely are seemingly ignored when it comes to making stark warnings based on the Afghan Alumni who apparently "returned to their homelands as well, infused with a dangerously radical 'jihad mentality'." 20 It is this backdrop which Ugarte and Turner signalled out to describe the social construction of Mindanao:

"This social construction is the 'enacted environment' (Weick 1977)... we 'actually shape future realities' (Morgan 1989: 93) while failing to appreciate that our perceptions could be based on the 'fallacy of misplaced concreteness' (Whitehead 1948). That is, unwarranted conclusions are drawn about the way things are (in this particular case, what the 'Abu Sayyaf' actually is)."21

Analysis of the Okonek kidnapping by the ASG will tell us how the social media users of Twitter commenting on the incident socially construct the ASG, and the conflict. Do they see the ASG as international jihadists linked to al Qaeda ${ }^{22}$ with "tentacles" 23 everywhere or as 0 'Brien noted, local 'bandits' 24 playing out the conflicts "agrarian roots" 25 ? 
Academics have commendably exposed the flaws ${ }^{26}$ and lack of evidence ${ }^{27}$ put forward to support any connections the ASG and the conflict in Mindanao has to the global jihad. ASG is a symptom of the wider "persistent fixation on Islam, radicalism and terrorism on part of the policy community" 28 in the region which is based on "anecdotal 'evidence"'29 that lacks basic "academic checkability" 30 . And while the academy trades scholastic blows, prominent exponents continue to publish new material with the ASG the go-to targets of Mindanao ${ }^{31}$ as the jihads breeding ground. The audience for these publications, as seen through Twitter, is likely to be well acquainted with the media savvy 'experts' of Jihad in Mindanao and their labels for the ASG. Here we see if, and how, the al Qaeda centric paradigm manifests, because we are starting to see a revival of a "false analogy" 32 on Mindanao in new publications, some from the same prominent authors who have yet to address the questions many raised previously.

\section{Significance of the Study}

Focus on a single incident such as here with Okonek isolate views of those on Twitter against such a backdrop. This analysis therefore starts where others have looked into this issue before, understanding that attention needs to be paid "from the perspective of local realities, not externally imposed organigrams" 33 , allowing us to assess perspectives used in this ASG incident. This is a pressing issue for the region and the conflict, as the ASG represent its most dangerous and volatile quantity - with the success of the current Aquino administrations attempted Bangsamoro peace deal reliant on ASG being inoculated by political reconciliation with the more stable and overtly political Moro Islamic Liberation Front (MILF). Avoiding questions about the identity and perception of the ASG will only further many of the current problems and likely lead to collapse of yet another attempt at peace in Mindanao. Without research into current understanding, it is difficult to see how the necessary public support can be obtained to achieve any success for new legislation and governance in Mindanao. It has been noted previously that avoiding the complexities of the ASGs meaning has lead to a self-perpetuating cycle:

"The Abu Sayyaf seems to be whoever the military claims it to be and given those who are labelled Abu Sayyaf, being buried six feet under, could no longer contest the military's claims of being just that ${ }^{\prime 34}$.

Understanding the result of this continued pattern for "convenient but misleading" 35 labelling will renew focus on the ASG and the conflict in Mindanao against the current backdrop of peace negotiations. Previous statements of how the ASG are 'perceived', such as here by O'Brien have not been well sourced, probably relying on the media representations rather than perceptions in the populous:

"Notably, when ASG is perceived throughout the Philippines as nothing more than an armed kidnapping gang, this creates new opportunities to gather intelligence from a population less tolerant of their purely criminal behavior... Periods of heightened criminal activity make it more difficult for a group like ASG to portray itself as motivated by a "greater good"-thus, law enforcement and security agencies can benefit from noting this and capitalizing on a group's ideological vulnerabilities, weakening its resilience to a point where, eventually, the group can no longer survive. ${ }^{136}$ 
This research uses Okonek and Twitter as the basis for an empirical foundation on the latest's perceptions of the ASG. With an evidentiary basis, this research disagrees with O'Brien and tells us that those who did label the ASG in the Okonek tweets were less inclined towards a criminal association.

As Woodier noted "reporting of the terror threat in Southeast Asia is often unintelligent, simplistic, and sensational. It often lacks perspective and proportion. Journalism on the ASG has given little consideration to what is perhaps the guiding question on terrorism understanding - "how do we know this?" 37 Creditably Ugarte and Turner decided to "test claims that the 'Abu Sayyaf' has features of organizations as conventionally portrayed in the organic metaphor and structural frame" 38 , finding significant disjuncture in the reporting of ASG structure compared to what could be independently verified. We thus ask: what narrative did the Twitter users on Okonek fall into?

\section{Background}

German couple Dr. Stefan Viktor Okonek and Henrike Dielen spent almost seven months in captivity after being seized from their yacht in April 2014, about 10 nautical miles off the coast of Rio Tuba in Palawan. With the backdrop of recent video decapitations of international journalists James Foley, Steven Sotloff, and David Haines by an Islamic extremist group in August and September of that year, the Abu Sayyaf group (ASG) had threatened to behead Dr. Okonek, even showing pictures of him standing on his supposed grave, unless a ransom demand of P250 million was paid, with the deadline set on October 17, 15:00 (local time). After a brief period of uncertainty between negotiations and deadline extensions, the ASG claimed that their ransom demand had been met, prompting the release of Okonek and Dielen on the evening of October 17 in Barangay Sandah, Patikul, Sulu ${ }^{39}$. During the most critical moments in October, in addition to extensive traditional media coverage such as local television and radio, the events garnered substantial attention in online news sources and social media with more international audiences.

The ASG has had a reported connection ${ }^{40}$ to international terror since $9 / 11$. Studies of their genealogy linked them most often (but not exclusively) to the global scope of al Qaeda ${ }^{41}$ or the more regional Jemaah Islamiya ${ }^{42}$. The ASG have become the Southeast Asian associate, offspring, franchise, affiliate 43 , or however it is termed, of the jihad lead by "messianic and mystic" 44 figures. This leads to "Official and media sources [that] continually refer to a social entity known as the 'Abu Sayyaf" 45 . As Docena astutely noted, the ASG became one of the foundations for the logic behind greater US military attention to the region in the war on terror:

"Speaking of the Abu Sayyaf, no mention of the group now seems to be complete without the phrase "al-Qaeda linked". News report after news report point out that the Abu Sayyaf is linked to Osama bin Laden's worldwide network and leave it at that - as though such a claim has been established and is not to be questioned any longer. ${ }^{\prime 46}$

Occasionally, this already murky portrayal is muddied further with the complexities of involvement with 'networked' crime 47 . As a result "the label 'Abu Sayyaf' gradually underwent a process of inflation" 48 into terrorism ${ }^{49}$. It is unclear whether or not this story of transition or inflation to terror is accurate, but nevertheless it is well reported that the ASG sits at the nexus ${ }^{50}$ of crime and terror. 


\section{Objectives of the Study}

This paper investigates Twitter data related to the Viktor Okonek and Henrike Dieter kidnapping by the ASG. It will determine perceptions of the ASG and associated organizations along with sentiments indicated in the tweets and explore statistically significant relationships. The analysis specifically addresses the following research questions:

1) What labels were used in the tweets to describe the Abu Sayyaf group?

2) What organizations that may be associated with the ASG were mentioned in the tweets?

3) What were the sentiments found in the tweets?

4) How are these variables related to each other and how are the labels used to describe the ASG predicted by these other variables?

Finally, the study also aims towards an understanding of perceptions and framing of terrorist and criminal organizations such as the ASG within the Mindanao context and its implications. Crucially this will be the first attempt to find and test any popular appreciation of the al Qaeda centric paradigm.

\section{Data and Methods}

Twitter data was collected via the Search API (application programming interface ${ }^{51}$ ) during the most critical days of the Viktor Okonek and Henrike Dieter kidnapping by the Abu Sayyaf Group. The data collection methods adopted for this paper are similar to those used by Burnap et al. ${ }^{52}$ and Cheong and Lee ${ }^{53}$ in order to determine keywords for queries, tweet gathering procedures, and utilization of other online facilities such as Google Trends. Data suggests an issue attention cycle of about 17 days when public attention and Twitter activity related to the event was most frequent. The sampling time frame for this study was the period of October 9th to 25th of 2014 from which we collected N=9026 tweets.

The sample was subjected to pre-processing and recoding prior to modelling, as described below. Collection was performed using JAVA code ran in NetBeans IDE to access and retrieve Twitter data automatically, and converted into CSV format. NVIVO, a Computer Assisted Qualitative Data Analysis Software (CAQDAS) was utilized for initial analysis of text contents via word frequencies, distribution, and clustering. Spreadsheet software was then used for coding, recoding, data checking, and creation of additional variables for further analysis based on initial findings from CAQDAS.

Upon creation of a consolidated dataset from the Twitter data sample, descriptive statistics and various statistical methods such as chi-square, bivariate correlation (Spearman's rho) were performed. All English tweets were then filtered $(\mathrm{N}=3524)$ for further analyses such as binary logistic regression with the aid of statistical analysis software. Collected data that were used in the analysis includes: Tweet details such as date creation, language, ID, text; Twitter user details such as name, location, description, account creation date, followers count, friends count, status count, etc.; Additional data were also obtained from sources such as IMF and World Bank, based on country location information for preliminary analyses such as bivariate correlations, though are not included in the regression models due to incomplete or unavailable user details that would result in a substantial decrease of samples size. 
Variables extensively used in the analysis are based on most frequently occurring words determined using CAQDAS and keywords and categories in sentiment analysis utilized in previous literature on terrorism ${ }^{54}$ or on event focused case studies ${ }^{55}$. On the basis that "classifying emotional content from informational content remains an important challenge in social media analysis"56, attempts at scaling sentiment become particularly salient when applied on a high publicity event such as this. Also when they involve a vaguely (and contested) criminal, terrorist, and extremist group, with rescue efforts coordinated by multiple agencies and countries, with outcomes affecting public perceptions. It must however be noted that aside from previously utilized approaches to sentiment analysis, analysts may still employ various critical and qualitative methods to understand tweet content and individual perspectives. Categories may also be customized in order to adjust to particular cultures or events that transpire.

The group labels and organization connection variables used are based on the study by Ugarte and Turner ${ }^{57}$ as well as the most frequent descriptions of the ASG from online news articles related to the kidnapping. Possible label variables included: bandit, criminal, extremist, fighter, Islamist, jihadist, kidnapper, militant, muslim/moslem, rebel, separatist, and terrorist.

Logistic regressions were applied to explain occurrence of the three most frequently used labels in tweets for the ASG, with variables such as sentiment categories, associated organizations, and if indicated location. The outcome variables: "Rebel", "Militant", and "Islamist" were coded 1 if it is mentioned in the tweet and 0 otherwise. The predictors were: Sentiment categories - Assessments of Threats, Response conceding to the ASG demands, Emotions of Fear or Anxiety, Response and Law Enforcement, and Assessments of Casualties; Mentioned Associations - Islamic State (ISIS), Moro Islamic Liberation Front (MILF), al Qaeda; and if location indicated is the Philippines. Data encoding, preprocessing, treatment and modelling, were conducted following statistical procedures for binary logistic regression ${ }^{58}$.

\section{Analysis and Results}

From the 9,026 tweets related to the ASG kidnapping, four out of five users with the most tweets were located in the Philippines (Refer to table 1). User descriptions indicated that these four users were news organizations/companies. Despite only being the third highest number of tweets, the most prominent among the top five is "DZBB Super Radyo" with 38,124 followers, Super Radyo DZBB $594 \mathrm{kHz}$ is the flagship AM radio station of Radio GMA Network Inc. in the Philippines - a subsidiary of one of the largest broadcasting networks in the country and one of the top AM stations in Metro Manila. Interestingly, 55 Tagalog tweets from DZBB Super Radyo focused on beheading (pagpugot), ransom, government offensive and rescue efforts, with more mention on the Armed Forces of the Philippines (AFP) and military related matters. Similarly, all of their five English tweets suggested means to counter ASG and to support government actions. Among the top five users, only "James Greid" from Canada was an individual user with 40 tweets, with the other three being primarily online news organizations.

When considering only English tweets, all of the top five users were from the Philippines. The aforementioned three: "PINOY NEWS PORTAL", "PHILIPPINE NEWS", and "PHL News Online" were still included in the top 5 users. However this time, the most prominent was "Rappler" with 518837 followers, Rappler is a comparatively recent news organization, based in the Philippines, known for pioneering new forms of internet based 'multi- 
platform storytelling', with services available on desktop and mobile browsers. Somewhat similar to DZBB, the English tweets posted by Rappler mostly highlighted hostages, deadline, and government reactions. The beheading aspect was also mentioned but not as frequent. Maria Ressa (alongside Gunaratna and Abuza) is the queen of the media darlings of Jihad in Mindanao, as noted above, founded Rappler ${ }^{59}$. Her work, which has confusingly straddled journalism and academia, unashamedly claims special and privileged access to classified materials, which she does not disclose. And though her work and has been regularly and extensively criticised, 60 her recent work - a "powerful narrative that glues together social networks - both physical and virtual - which spread the jihadi virus form bin Laden to Facebook"61 is a pseudo-academic study of an event. Probably best illustrated in the 8 pages that list the "Cast of Characters" and 12 pages of hard to understand network maps, which are only very briefly explained, though not methodologically. Where this data came from is anyone's guess. The various nodes on the 'sociograms' look complicated and presumably are there to give the book some academic heft so that 'the network' connection is irrefutable, with such complicated diagrams to prove it.

Ressa is at the centre of this issue, she owns a social media company to disseminate the $a l$ Qaeda centric paradigm. She does this by pointing vaguely to evils found in social media and unscientifically makes associative claims such as Filipinos (or Filipino organizations, the ASG included) being interconnected to the global terrorist scourge:

"Filipinos connect with al-Qaeda-linked groups in Somalia and Yemen. The black flagembedded in al-Qaeda lore - pops up on websites and Facebook pages from around the world, including the Philippines, Indonesia, the Middle East, Afghanistan, Australia and North Africa." ${ }^{\prime 62}$

It must be noted that although Ressa has not collected substantial amounts of data or applied Burnap et al's or Cheong and Lee's methods. After seeing some dastardly looking Facebook pages, she has used them to artificially modernise the connections between Mindanao and the jihad. As such, there is no justification as to why the few al Qaeda decorated Facebook pages may be more significant than the many more with memes of cats playing the piano or dogs on surfboards.

Among users who specified their locations, the top five countries with the most number of tweets were: The Philippines, Indonesia, Germany, Malaysia, and USA. These possibly relate to the geographic distance, number of Filipinos living in the country, and the involvement of the country (in the case of Germany) to the kidnapping. As for English tweets that comprised $39.04 \%$ of the sample, the most numerous came from: Philippines, Malaysia, Nigeria, Bahrain, and UK. There were only 59 (1.67\%) English tweets that came from Germany.

\section{Labels for the Abu Sayyaf Group, other organizations mentioned, and sentiments in tweets}

Rebels and Militants were the most frequently used labels $(15.75 \%$ and $14.10 \%$ respectively) for the Abu Sayyaf in English tweets. Only 3.38\% of the tweets label them as Islamists. Other labels appear less than $1 \%$ among the tweets (Refer to Table 2).

For the "Rebel" label, looking at the strongest correlations that these two labels have with other variables: the use of the label "rebel" was found to have positive significant correlations with sentiments related to threat assessment $(.311, \mathrm{p}<0.001)$ and responses 
conceding to the ASG demands $(.404, \mathrm{p}<0.001)$, along with the distance of the tweet location country from Jolo $(.276, \mathrm{p}<0.001)$, GDP per capita of the country $(.248, \mathrm{p}<0.001)$ and if the country is predominantly Muslim $(.366,<0.001)$.

On the other hand, the "militant" label was found to have a strong positive correlation with the "Islamist" label $(.407, \mathrm{p}<0.001)$ along with the distance of the tweet location country from Jolo $(.308, \mathrm{p}<0.001)$, and had a negative correlation with sentiments related to law enforcement $(-.155, \mathrm{p}<0.001)$.

Only $1.42 \%$ of the English tweets mentioned ISIS, while organizations such as the MILF and Al Qaeda were mentioned less than 1\% of the time. Less than a handful tweets had mentioned the MNLF or the Jemaah Islamiyah.

Majority (61.21\%) of the tweets in English contained sentiments that assess threats such as abduction and kidnapping of hostages. About half (43.44\%) contained words pertaining to responses such as payment of ransom, that indicate negotiation or concession to the demands of the captors. Less than a quarter of the tweets contained the more evocative of categories such as fear anxiety $(20.66 \%)$ and pessimistic scenarios of casualty assessment $(14.22 \%)$. It is then worth mentioning that although the top Twitter users with the most followers such as DZBB and Rappler, references to government response, the category of Response and Law Enforcement sentiment, was found to be only in $16.69 \%$ of the tweets.

\section{Correlations of sentiment category variables}

Utilizing similar variable categories employed in sentiment analysis by other researchers on civilian sentiment and response to terrorism events via Twitter, results of this study indicate that sentiments that contain assessments of threats had positive significant correlations with the sentiments of responses pertaining to negotiating or conceding to ASG demands $(.256, \mathrm{p}<0.001)$, while negatively correlated with responses mentioning law enforcement and government action $(-.272, \mathrm{p}<0.001)$. As mentioned previously, it was found to be positively correlated with the label of "rebel". Whether the tweet was from Germany was found not to be significantly correlated to the sentiment, but it was also found that the distance (in terms of kilometers) of Jolo to the tweet source location was positively correlated $(.278, \mathrm{p}<0.001)$, that is to say - the farther the distance, the more of such sentiments were observed.

The conceding responses category was found to be negatively correlated to sentiments containing assessments of casualties $(-.211, \mathrm{p}<0.001)$, while positively correlated to the "rebel" label $(.404, \mathrm{p}<0.001)$.

Sentiments that contain emotions of fear and anxiety were found to be significantly correlated with assessments of casualties $(.597, \mathrm{p}<0.001)$ as words that evoke worrisome and fearful emotions are usually accompanied by words detailing consequences to the victims.

Interestingly, sentiments that mentioned responses of law enforcement had a positive correlation if the tweets came from the Philippines $(.229, \mathrm{p}<0.001)$. While a negative correlation with distance of Jolo to the tweet source location $(-.282, \mathrm{p}<0.001)$, that is to say - the farther the distance, the less responses of law enforcement were observed.

Sentiments that contain assessments of casualties had a negative correlation with the label of "militant" $(.130, \mathrm{p}<0.001)$. 
Overall, it was also observed for the preliminary analysis that the GDP per Capita of the country were the tweet was located had positive correlations with the threat assessment, conceding responses, fearful emotion, casualty assessment sentiments, while a negative correlation with law enforcement responses. Further, it was also found that distance of the country were the tweet was located had positive correlations with the threat assessment, conceding responses, casualty assessment sentiments, while also having a negative correlation with law enforcement responses.

\section{Significant Predictors of Labels}

For the binary logistic regression analyses, results show that sentiments that contain 'assessment of threats' and 'responses that concede to the kidnappers' demands' significantly predicted usage of "Rebel", "Militant", and "Islamist" labels for the ASG. Analyses on "Rebel" and "Islamist" revealed positive coefficients for these predictors, whereas "Militant" had a negative coefficient. As shown in Table 3, exp(b) values indicate that when the sentiments increase the more likely that the two labels are used, while it is the inverse for militant. Test of the full model against a constant only model was statistically significant, indicating that the predictors as a set reliably distinguished usage of labels for the ASG. The model explained a significant proportion of variance on the usage of the labels, particularly for "Rebel" (Nagelkerke $\mathrm{R}^{2}=.45$ ). Significant associated organizations predictors was the MILF for the "Islamist" label. While for the "Militant" label, the ISIS association predictor had a negative coefficient.

These findings may also be interpreted as usage of the two labels evoking associated sentiments of threats and necessary responses taken more seriously. Or as congruent to the Rebel or Islamist perceived identity. Curiously, though the significant predictor of location specified being the Philippines seem to suggest that these labels are less likely to be used if the tweet location is specified as originated from the country.

\section{Discussion}

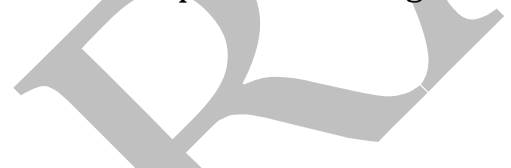

What labels were used in the tweets to describe the Abu Sayyaf group? What are the most frequent labels used in English tweets?

The two most common labels used (see table 2a) denote a distinct political element to the ASG - 'rebel' and 'militant'. Kidnapping is not uncommon in the Philippines ${ }^{63}$ and often the more common label associated in kidnappings centres on the criminality - usually 'bandit' or 'criminal'. As O'Brien noted, the "intersection" 64 of crime and terror adds a further level of complexity to the ASG. As such the research seems to show how the ASG in the Okonek case have had their status 'upgraded' as it were from mere banditry to some element of political labelling. The ASG are an enemy of Filipino state forces and it is unlikely that on any issue they would be labelled as anything other than a term denoting them as insurgents of the state.

The second group of terms, which would demonstrate some recital of the Al Qaeda centric paradigm, are Islamist, Muslim, and Jihadist, with the three being minority labels. Even on an issue of international concern, the kidnapping for ransom of foreign nationals, Twitter commenters who chose to label the ASG, interpreted the ASG as local insurgents. The public is used to seeing ASG as an enemy of the Filipino state needing state sanctioned 
military countenance and the labels suggest this is understanding behind the primarily label for the ASG in this case. The evidence of this is likely to be well received in policy circles in Manila advocating for continued military operations in the region. If the general public is of a similar mind to the Twitter users on the Okonek case, it suggests that a cemented view of the ASG as an internal struggle for political power in Mindanao. This is despite the overtly wild claims of internationally fuelled and facilitated terrorism by Ressa, Abuza and Gunaratna.

This finding lends support to the importance of the complexities of Filipino politics, identity and citizenship, reflected in very $21^{\text {st }}$ century expressions on the conflict. The complex physical and human geography of the nation and Mindanao itself mean the diverse ethno-cultural heritage of the conflict remain pertinent issues. Here the evidence suggests they are more pertinent, rather than Mindanao and the ASG serving as a sanctuary for jihadists. These findings reinforce the recommendation that further research is needed on "emotional geography" 65 as Woon terms it to further examine the seemingly realized fragmented sense of nationhood, identity and reality at play. As Woon noted from fieldwork in the region "it is through this process that more expansive and nuanced knowledges of violence and terror can be generated, thereby invalidating secondary, discursive analyses of these events as the sole dominant reflection of reality,"66. The secondary discursive labels of the al Qaeda centric paradigm on the ASG have been detailed and nuanced and as we see next, invalidated by social media fieldwork ${ }^{67}$.

This research allowed us to ask if the ASG were seen as pirates in paradise ${ }^{68}$ or jihadists in paradise? And the answer was neither, these two longstanding narratives of the ASG were not found significantly and the emerging Rebel and Militant labels may surprise close observers of commentary on the ASG. This suggests a more domestically and politically sensitive Twitter commentarial than represented in the work of the Al-Qaeda centric paradigm exponents.

While 64.39\% (2269) of the English tweets had no label for the ASG, the fact that $35.61 \%$ (1255) of the tweets did seek to label the ASG does demonstrate an ASG labelling issue in a third of tweets. The relative conformity in those tweets to label ASG in political terms should not be regarded as representative on its own though. Labels are of course difficult ${ }^{69}$; hence this research. Given the nature of commentary on the ASG the next marker is often organizational.

What organizations that may be associated with the ASG were mentioned in the tweets?

As a marker of ASG's connections, the tweets on the Okonek incident showed only $2.58 \%$ (91) of English tweets added an organization to the ASG. Perhaps, the ASG is understood as an organization in its own right, and that the need to 'link' to other entities is only a minor concern. Where an organization (and we use this term loosely, with the term group already taken by the ASG name itself) is mentioned in the same tweet, the currency of ISIS as the 'latest', most publicized organization at the time, appears to supplant the longer term regional Jemaah Islamiyah, 50 tweets against just 2 . Links to organizations are not prevalent and the tiny minority of tweets that did link the ASG looked to the most newsworthy - ISIS, despite it being the most remote. 
Contrast the $2 \%$ figure of organisation 'linkages' with the scope of 'expert' academic attention placed on linkage and we have empiricied a significant disjuncture. As Fealy and Thayer noted "international and regional terrorism specialists often use 'linkage' in such an ill-defined and indiscriminate way that lacks analytical acuity and explanatory power"70. Twitter users motives cannot be read from this data but it appears as if Colliers warning against "assuming a world of clearly bounded organizations"71 is not needed for Twitter users who may understand the complexities and informality of social groupings well. Rather, the advice remains pertinent to those for whom the issue of organisational linkage remains a primary concern - particularly amongst some journalists and academics.

\section{What were the sentiments found in the tweets?}

Over the course of the events, the majority of the sentiments found in the tweets assessed the physical threats to the victims (61.21\%), expressed concession towards the demands of the captors $(43.44 \%)$, and conveyed anxiety and fear $(20.66 \%)$. Interestingly, though some $(14.22 \%)$ had sentiments describing casualties and even a few $(1.42 \%)$ who foresaw slightly optimistic views that the victims may escape, almost nobody had expressed shock in their tweets. This may be attributed to the rampant occurrences of kidnapping that plague the country, particularly in rural areas. Such sentiments suggest that it has become an unfortunate part of life and a lucrative endeavour for lawless elements to engage in. And that the relatively rational course of action is to concede to the kidnappers demands rather than risk harm, particularly when dealing with those considered as rebels that appear to be beyond the state and its societal norms.

The "tremendous growth"72 in the study of terrorism through novel and potentially useful methodologies such as informatics ${ }^{73}$ present a renewed chance to bamboozle the public. By focusing on social network analysis ${ }^{74}$ on groups such as ASG, or terrorism more broadly the danger again is that it may mislead the public. Studies that have looked into the Twitter activity of those afflicted by conflict (such as in the Mexican Drug War ${ }^{75}$ ) suggest uses beyond immediate crisis ${ }^{76}$. Information sharing and the ecosystem of commentary is far less risky and less bounded by proximity to the events. Commenting on the ASG and Okonek we have seen that the user generated channel 77 differs from the academic, media and policy channels.

\section{Conclusions}

As the findings of this study have revealed, depictions of the ASG as a terrorist organization has not stuck. That they are perceived as primarily rebels, militants, or Islamists, by those who chose to label them, despite the milieu of atrocities carried out by other extremists clearly visible online, is an important insight. With the group itself threatening to mimic the execution of their captives unless their demands were met, this ISIS, al Qaeda mimicry did not lead to labelling and association compatible to the al Qaeda centric paradigm. However, the findings also indicated that tweets from the Philippines were less likely to use these labels. That may imply that either the locals do not classify the ASG with these labels or that an international audience chooses to brand the ASG as such in another way. In either case, the ASG has not been significantly perceived as international terrorists. As Michael Stohl has eloquently argued in his critical analysis of knowledge claims and terrorism; "the audience is not persuaded"78 even when presented with an overwhelming diet of claims on new terror networks. Additional future introspection should be done to determine as to whether the state, media, or 
propagandists had failed to persuade the netizens of the ASG being; terrorists doing criminal acts, criminals engaging in terrorist acts, or simply opportunists wanting to make a quick buck.

The repeated reports that Mindanao threatens to be 'the next Afghanistan' which are echoed in the social media posts of organisations like Rappler are not replicated by individual Twitter users. On this topic we can see that Twitter is not an echo chamber ${ }^{79}$ for the al Qaeda centric paradigm. This is despite 'Afghanistan cautioning' becoming well cemented in Filipino domestic policy towards Mindanao, and outside in the regional second front informed policies explicit in many diplomatic relations. Arguably such cautioning was at its peak in 2005, but repeated in 200980 and then affirmed in 2011, following the Wikileaks diplomatic cable release in $2010^{81}$ when various press stories circulated that were both embarrassing 82 for US-Filipino relations and provide some rare detailed evidence of the extent to which the US was providing tactical and intelligence support ${ }^{83}$. This situation however did not come to pass overnight, but rather because of the protracted nature of the conflict and the history of rebellion, insurgency and anticolonialism in Mindanao, the region has always been, and continues to be opportunely deemed as a hotbed for insurgency.

The Philippines has been described as an obvious hideout and sanctuary for the global jihad. A 'host' country, carrier of the radicalisation infection where "the essential dilemma is the same. How does one separate the terrorist parasite from its unwilling host, without doing fatal violence to the patient?"84. This rather oblique view is not just simplified to the point of redundancy but is also not represented in the data collected here. The labels Rebel and Militant do not infer the pathology of a radicalised ideology and so public support for campaigns will need to address the understanding behind this disparity.

With little by the way of verifiable empirical study on the reality of the ASG, dependence on secondary, over field-work based primary research has furthered the drought of country specialists. "Self-styled terrorologists and parachute journalists" 85 have attempted to set the narrative and political agenda. There continues to be a "a critical gap which has emerged because of standard interpretations have tended to follow officially approved direction of a myriad self-referencing military studies" 86 with many authors owing all their 'research' and basing their conclusions from, the word of the Philippine Military and other state officials. In short, much of what has been written about the jihad and Mindanao has been framed in specific US security terms ${ }^{87}$. Despite this, the Twitter users on the Okonek case appear to be immune, and perhaps know better than to swallow a poorly argued and evidenced line by those who often fail to even spend time in their country.

Although the conflict in Mindanao is essentially local, the supposed "international dimension as the separatists established links with Islamic radicals in other parts of the Muslim world" 88 , were not evidenced in the data. Only 3.38\% of English tweets labelled them as Islamists, and only $2.58 \%$ linked them to other organizations. This is similar to Thayer, who argued that country specialists "bottom up' view directly challenges key assumptions of international and regional terrorist experts." 89 The labels, sentiments and organisations used on the Okonek case offers Twitter users a bottom up voice to reflect the diet of the ASG coverage consumed. The natural conclusion is that the international Islamist dimension is not shared from 'the bottom'. 


\section{Notes}

1 Mark Bowden, "Jihadists in Paradise," The Atlantic, March 2007, http://www.theatlantic.com/magazine/archive/2007/03/jihadists-in-paradise/305613/.

${ }^{2}$ For a comprehensive report into the modern US-Philippine military alliance see Docena, $\mathrm{H}$. (2007). "At the Door of all the East": The Philippines in United States Military Strategy. Focus on the Global South. Retrieved from http://focusweb.org/content/door-all-east

${ }^{3}$ Ambassador Albert del Rosario, "A Progress Report on the Philippines" (The Heritage Foundation, March 27, 2002), http://www.heritage.org/research/lecture/a-progress-reporton-the-philippines.

${ }^{4}$ This is despite the ASG only previously being of interest to American anthropologists, rather than politicians, for their challenge to Filipino Muslim identity, see Charles O. Frake, "Abu Sayyaf: Displays of Violence and the Proliferation of Contested Identities among Philippine Muslims," \iAmerican Anthropologist 100, no. 1 (March 1, 1998): 41-54, doi:10.1525/aa.1998.100.1.41.

${ }^{5}$ Andrew Tan, Security Strategies in the Asia-Pacific: The United States' "Second Front" in Southeast Asia (New York: Palgrave Macmillan, 2011); Kenneth Conboy, The Second Front: Inside Asia's Most Dangerous Terrorist Network (Equinox Publishing, 2005); John Gershman, "Is Southeast Asia the Second Front?," Foreign Affairs 81, no. 4 (2002): 60, doi:10.2307/20033240; Kumar Ramakrishna, "Countering Radical Islam in Southeast Asia: The Need to Confront the Functional and Ideological 'enabling Environment.,'" in Terrorism and Violence in Southeast Asia: Transnational Challenges to States and Regional Stability, ed. Paul J. Smith (East Gate Books, 2005), 145-68; Christopher S. Bond, The Next Front: Southeast Asia and the Road to Global Peace with Islam, 1 edition (Chichester: Wiley, 2009); Andrew Tan, "Southeast Asia as the 'second Front' in the War against Terrorism: Evaluating the Threat and Responses," Terrorism and Political Violence 15, no. 2 (2003): 112-38, doi:10.1080/09546550312331293067.

${ }^{6}$ Collier, "Terrorism: Evolving Regional Alliances and State Failure in Mindanao," 26.

7 "Al-Qaeda and Political Terrorism in Southeast Asia," in Terrorism and Violence in Southeast Asia: Transnational Challenges to States and Regional Stability, by Paul J. Smith, 2005, 82.

${ }^{8}$ Andrew Hoskins and Ben O'Loughlin, War and Media (Polity Press, 2010).

${ }^{9}$ Eduardo F. Ugarte, "'In a Wilderness of Mirrors': The Use and Abuse of the 'Abu Sayyaf' Label in the Philippines," South East Asia Research 18, no. 3 (September 1, 2010): 373-413, doi:10.5367/sear.2010.0002.

${ }^{10}$ Philip Jenkins, Images of Terror: What We Can and Can't Know about Terrorism (New York: Aldine de Gruyter, 2003), 193.

${ }^{11}$ Docena, "Philippines: Fanning the Flames of War."

${ }^{12}$ Bilveer Singh, The Talibanization of Southeast Asia: Losing the War on Terror to Islamist Extremists (New Delhi: Praeger, 2007), ix.

${ }^{13}$ Andrew Tan and Kumar Ramakrishna, The New Terrorism: Anatomy, Trends, and CounterStrategies (Eastern Universities Press, 2002), 10.

${ }^{14}$ GMA News, "NDF: After Clinton Visit, Mindanao May Be next Afghanistan," GMA News Online, November 2009, http://www.gmanetwork.com/news/story/176946/news/nation/ndf-after-clinton-visitmindanao-may-be-next-afghanistan; Pia Lee-Brago, "Mindanao Could Be next Afghanistan - US 


Diplomat," Philstar.com, April 2005,
http://www.philstar.com/headlines/273463/mindanao-could-be-next-afghanistan---usdiplomat; Kit Collier, "The Philippines' Sanctuaries of Terror," Project Syndicate, May 2, 2006, http://www.project-syndicate.org/commentary/the-philippines--sanctuaries-of-terror/english.

${ }^{15}$ Examples of the tenants of the sanctuary and breeding ground arguments, such as AbdulAhad, G. (2012, April 30). 'Al-Qaida's wretched utopia and the battle for hearts and minds'. the Guardian. Retrieved October 20, 2013, from http://www.theguardian.com/world/2012/apr/30/alqaida-yemen-jihadis-sharia-law The socalled 'Arc of Terror' idea as demonstrated in pieces such as Spencer, R. (2010, January 31). Recruits seek out al-Qaeda's deadly embrace across a growing arc of jihadist terror. Telegraph.co.uk. Retrieved from http://www.telegraph.co.uk/news/worldnews/middleeast/saudiarabia/7105454/Recruitsseek-out-al-Qaedas-deadly-embrace-across-a-growing-arc-of-jihadist-terror.html ${ }^{16}$ Fernando Reinares, "Radicalisation Processes Leading to Acts of Terrorism" (European Commission's Expert Group on Violent Radicalisation, 2008), 15, http://www.clingendael.nl/sites/default/files/20080500_cscp_report_vries.pdf.

${ }^{17}$ Rohan Gunaratna, Inside Al Qaeda : Global Network of Terror, Reissue, 2003, 232.

${ }^{18}$ Damien Kingsbury, Violence in between: Conflict and Security in Archipelagic Southeast Asia (Clayton; Singapore: Monash Asia Institute ; Institute of Southeast Asian Studies, 2005), 72.

${ }^{19}$ Natasha Hamilton-Hart, "Terrorism in Southeast Asia: Expert Analysis, Myopia and Fantasy," The Pacific Review 18, no. 3 (2005): 316, doi:10.1080/09512740500188845.

${ }^{20}$ Barry Desker and Kumar Ramakrishna, "Forging an Indirect Strategy in Southeast Asia," The Washington Quarterly 25, no. 2 (2002): 161.

${ }^{21}$ Ugarte and Turner, "What Is the 'Abu Sayyaf'? How Labels Shape Reality," 399.

${ }^{22}$ Dirk J. Barreveld, Terrorism in the Philippines: The Bloody Trail of Abu Sayyaf, Bin Laden's East Asian Connection (iUniverse, 2001).

${ }^{23}$ Zachary Abuza, "Tentacles of Terror: Al Qaeda's Southeast Asian Network," Contemporary Southeast Asia 24, no. 3 (December 2002): 427+; Shawn Brimley, "Tentacles of Jihad: Targeting Transnational Support Networks," Parameters 36, no. 2 (June 22, 2006): 30.

${ }^{24}$ Eric Gutierrez, "From Ilaga to Abu Sayyaf: New Entrepreneurs in Violence and Their Impact on Local Politics in Mindanao," Philippine Political Science Journal 24, no. 47 (December 1, 2003): 145-78, doi:10.1080/01154451.2003.9754250; Banlaoi, "The Abu Sayyaf Group: From Mere Banditry to Genuine Terrorism"; Kit Collier, "A Carnival of Crime: The Enigma of the Abu Sayyaf," Conflict, Community, and Criminality in Southeast Asia and Australia, Center for Strategic \& International Studies (CSIS). S, 2009, 44-57.

${ }^{25}$ Sietze Vellema, Jr, Saturnino M. Borras, and Jr, Francisco Lara, "The Agrarian Roots of Contemporary Violent Conflict in Mindanao, Southern Philippines," Journal of Agrarian Change 11, no. 3 (July 2011): 298-320, doi:10.1111/j.1471-0366.2011.00311.x.

${ }^{26}$ Michael K. Connors, "War on Error and the Southern Fire: How Terrorism Analysts Get It Wrong," Critical Asian Studies 38, no. 1 (2006): 151-75, doi:10.1080/14672710600556528.

${ }^{27}$ Graham Brown, "The Perils of Terrorism: Chinese Whispers, Kevin Bacon and Al Qaeda in Southeast Asia - A Review Essay," Intelligence and National Security 21, no. 1 (2006): 150-62, doi:10.1080/02684520600568626.

${ }^{28}$ Joseph Chinyong Liow, "International Jihad and Muslim Radicalism in Thailand?: Toward an Alternative Interpretation," Asia Policy 2, no. 1 (2006): 92.

${ }^{29}$ Ibid., 93.

${ }^{30}$ Brown, "The Perils of Terrorism," 151. 
$\begin{array}{ccccc}{ }^{31} \text { Maria Ressa, From Bin Laden to Facebook } 10 \text { Days of Abduction, } 10 \text { Years of Terrorism } \\ \text { (Hackensack, NJ: } \quad \text { World } \quad \text { Scientific } & \text { Pub. }\end{array}$ http://search.ebscohost.com/login. aspx?direct=true\&scope $=$ site $\& d b=$ lebk\&db=nlabk\&AN $=57$ 5392.

32 Joseph Chinyong Liow, "ISIS Goes to Asia," Foreign Affairs, September 19, 2014, http://www.foreignaffairs.com/articles/142004/joseph-chinyong-liow/isis-goes-to-asia.

${ }^{33}$ Kit Collier, "Terrorism: Evolving Regional Alliances and State Failure in Mindanao," Southeast Asian Affairs 2006, no. 1 (2006): 27.

${ }^{34}$ Docena, "Philippines: Fanning the Flames of War."

${ }^{35}$ Ugarte and Turner, "What Is the 'Abu Sayyaf'? How Labels Shape Reality," 398.

${ }^{36}$ McKenzie O'Brien, "Fluctuations Between Crime and Terror: The Case of Abu Sayyaf\&\#039;s Kidnapping Activities," Terrorism and Political Violence 24, no. 2 (2012): 333, doi:10.1080/09546553.2011.648679.

37 Jenkins, Images of Terror: What We Can and Can't Know about Terrorism, 193.

${ }^{38}$ Ugarte and Turner, "What Is the 'Abu Sayyaf'? How Labels Shape Reality," 404.

39 Julie Alipala-Inquirer and Cynthia D. Balana, "After Freed Germans, at Least 11 Hostages Still in Abu Sayyaf Hands," Globalnation.inquirer.net, October 19, 2014, http://globalnation.inquirer.net/112923/after-freed-germans-at-least-11-hostages-still-in-abusayyaf-hands/.

${ }^{40}$ Michael S. James and and John K. Cooley, "The Abu Sayyaf-Al Qaeda Connection," ABC News, January 6, 2006, http://abcnews.go.com/International/story?id=79205\&page=1.

${ }^{41}$ David Martin Jones, M. L. R. Smith, and Mark Weeding, "Looking for the Pattern: Al Qaeda in Southeast Asia-The Genealogy of a Terror Network," Studies in Conflict \& Terrorism 26, no. 6 (2003): 443-57, doi:10.1080/10576100390248284.

${ }^{42}$ Zachary Abuza, "Funding Terrorism in Southeast Asia: The Financial Network of Al Qaeda and Jemaah Islamiya," Contemporary Southeast Asia: A Journal of International and Strategic Affairs 25, no. 2 (2003): 169-99.

${ }^{43}$ David Ronfeldt, "Al Qaeda and Its Affiliates: A Global Tribe Waging Segmental Warfare?," First Monday 10, no. 3 (March 7, 2005), doi:10.5210/fm.v10i3.1214; John Rollins, Al Qaeda and Affiliates: Historical Perspective, Global Presence, and Implications for U. S. Policy (DIANE Publishing, 2010); Thomas Joscelyn, "Global Al Qaeda: Affiliates, Objectives, and Future Challenges," The Long War Journal 18 (2013), http://defenddemocracy.org/content/uploads/documents/TJFormattedTestimony7_18.pdf.

${ }^{44}$ Robert East, Terror Truncated: The Decline of the Abu Sayyaf Group from the Crucial Year 2002 (Cambridge Scholars Publishing, 2013), 1.

${ }^{45}$ Eduardo F. Ugarte and Mark Macdonald Turner, "What Is the 'Abu Sayyaf'? How Labels Shape Reality," Pacific Review 24, no. 4 (2011): 410, doi:10.1080/09512748.2011.596558.

${ }^{46}$ Herbert Docena, "Philippines: Fanning the Flames of War," Asia Times Online, May 2, 2007, http://www.atimes.com/atimes/Southeast_Asia/IE02Ae03.html.

${ }^{47}$ Clarita R. Carlos, The Links between Organized Crime and Terrorism: The Philippines and the Abu Sayyaf, October 2002.

${ }^{48}$ Ugarte and Turner, "What Is the 'Abu Sayyaf'? How Labels Shape Reality," 411.

${ }^{49}$ Rommel C. Banlaoi, "The Abu Sayyaf Group: From Mere Banditry to Genuine Terrorism," Southeast Asian Affairs 2006, no. 1 (2006): 247-62.

${ }^{50}$ Steven Hutchinson and Pat O'malley, "A Crime-Terror Nexus? Thinking on Some of the Links between Terrorism and Criminality," Studies in Conflict \& Terrorism 30, no. 12 (2007): 10951107, doi:10.1080/10576100701670870. 
${ }^{51}$ The Twitter Search API (application programming interface) allows queries against the indices of recent or popular Tweets similar to the Search feature available in Twitter mobile or web clients, such as Twitter.com search. For more details and documentation refer to https://dev.twitter.com/rest/public/search

${ }^{52}$ Pete Burnap et al., "Tweeting the Terror: Modelling the Social Media Reaction to the Woolwich Terrorist Attack," Social Network Analysis and Mining 4, no. 1 (December 2014), doi:10.1007/s13278-014-0206-4.

${ }^{53}$ Marc Cheong and Vincent C. S. Lee, "A Microblogging-Based Approach to Terrorism Informatics: Exploration and Chronicling Civilian Sentiment and Response to Terrorism Events via Twitter," Information Systems Frontiers 13, no. 1 (March 1, 2011): 45-59, doi:10.1007/s10796-010-9273-x.

${ }^{54}$ Ibid.

${ }^{55}$ Wei Shi, Hongwei Wang, and Shaoyi He, "Sentiment Analysis of Chinese Microblogging Based on Sentiment Ontology: A Case Study of '7.23 Wenzhou Train Collision,"' Connection Science 25, no. 4 (December 1, 2013): 161-78, doi:10.1080/09540091.2013.851172.

${ }^{56}$ Pollyanna Gonçalves, Fabrício Benevenuto, and Meeyoung Cha, "PANAS-T: A Pychometric Scale for Measuring Sentiments on Twitter," arXiv:1308.1857 [physics], August 8, 2013, http://arxiv.org/abs/1308.1857.

${ }^{57}$ Ugarte and Turner, "What Is the 'Abu Sayyaf'? How Labels Shape Reality."

58 Andy Field, Discovering Statistics Using IBM SPSS Statistics (Sage, 2013), https://books.google.co.uk/books?hl=en\&lr=\&id=c0Wk9luBmAoC\&oi=fnd\&pg=PP2\&dq=Discov ering+Statistics+using+SPSS\&ots=LaBpGMXy1A\&sig=5yCcX-Szt0mbinIPBT1Dtj2fa8g; Barbara G. Tabachnick and Linda S. Fidell, Using Multivariate Statistics, 5 edition (Boston: Pearson, 2006); Chao-Ying Joanne Peng and Tak-Shing Harry So, "Logistic Regression Analysis and Reporting: A Primer," Understanding Statistics: Statistical Issues in Psychology, Education, and the Social Sciences 1, no. 1 (2002): 31-70.

${ }^{59}$ Maria Ressa, Seeds of Terror: An Eyewitness Account of Al-Qaeda's Newest Center (Free Press, 2011); Ressa, From Bin Laden to Facebook 10 Days of Abduction, 10 Years of Terrorism.

${ }^{60}$ Hamilton-Hart, "Terrorism in Southeast Asia."

${ }^{61}$ Ressa, From Bin Laden to Facebook 10 Days of Abduction, 10 Years of Terrorism, v.

62 Ibid.

${ }^{63}$ Eduardo F. Ugarte, "The Phenomenon of Kidnapping in the Southern Philippines: An Overview," South East Asia Research 16, no. 3 (November 1, 2008): 293-341.

${ }^{64}$ O'Brien, "Fluctuations Between Crime and Terror," 320.

${ }^{65}$ Chih Yuan Woon, "For 'emotional Fieldwork' in Critical Geopolitical Research on Violence and Terrorism," Political Geography 33 (March 2013): 31-41, doi:10.1016/j.polgeo.2012.11.007; Chih Yuan Woon, "Undoing Violence, Unbounding Precarity: Beyond the Frames of Terror in the Philippines," Geoforum 42, no. 3 (June 2011): 285-96, doi:10.1016/j.geoforum.2011.04.003.

${ }^{66}$ Woon, "For 'emotional Fieldwork' in Critical Geopolitical Research on Violence and Terrorism," 34.

${ }^{67}$ Jeffrey S. Juris, "Reflections On\# Occupy Everywhere: Social Media, Public Space, and Emerging Logics of Aggregation," American Ethnologist 39, no. 2 (2012): 259-79; Isabelle Côté, "Fieldwork in the Era of Social Media: Opportunities and Challenges," PS: Political Science \& Politics 46, no. 03 (2013): 615-19; Annette Markham, "Fieldwork in Social Media: What Would Malinowski Do?," Qualitative Communication Research 2, no. 4 (2013): 434-46.

${ }^{68}$ Stefan Eklöf, Pirates in Paradise: A Modern History of Southeast Asia's Maritime Marauders (NIAS Press, 2006). 
${ }^{69}$ Mike Thelwall, Kevan Buckley, and Georgios Paltoglou, "Sentiment in Twitter Events," Journal of the American Society for Information Science and Technology 62, no. 2 (2011): 40618.

${ }^{70}$ Carlyle Alan Thayer and Greg Fealy, "Problematising 'linkages' between Southeast Asian and International Terrorism," in Security Politics in the Asia-Pacific: A Regional-Global Nexus?, ed. William T. Tow (Cambridge University Press, 2009), 226.

${ }^{71}$ Collier, "Terrorism: Evolving Regional Alliances and State Failure in Mindanao," 30.

${ }^{72}$ Hsinchun Chen et al., "Introduction to Special Issue on Terrorism Informatics," Information Systems Frontiers 13, no. 1 (January 13, 2011): 1-3, doi:10.1007/s10796-010-9293-6.

${ }^{73}$ Hsinchun Chen et al., Terrorism Informatics: Knowledge Management and Data Mining for Homeland Security (Springer Science \& Business Media, 2008).

${ }^{74}$ Arie Perliger and Ami Pedahzur, "Social Network Analysis in the Study of Terrorism and Political Violence," PS: Political Science \& Politics 44, no. 01 (January 2011): 45-50, doi:10.1017/S1049096510001848.

${ }^{75}$ Andrés Monroy-Hernández et al., "The New War Correspondents: The Rise of Civic Media Curation in Urban Warfare," in Proceedings of the 2013 Conference on Computer Supported Cooperative Work, CSCW '13 (New York, NY, USA: ACM, 2013), 1443-52, doi:10.1145/2441776.2441938.

${ }^{76}$ Onook Oh, Manish Agrawal, and H. Raghav Rao, "Information Control and Terrorism: Tracking the Mumbai Terrorist Attack through Twitter," Information Systems Frontiers 13, no. 1 (September 25, 2010): 33-43, doi:10.1007/s10796-010-9275-8.

77 José Van Dijck, "Users like You? Theorizing Agency in User-Generated Content," Media, Culture, and Society 31, no. 1 (2009): 41; Neil Thurman, "Forums for Citizen Journalists? Adoption of User Generated Content Initiatives by Online News Media," New Media \& Society 10, no. 1 (2008): 139-57.

${ }^{78}$ Michael Stohl, "Don't Confuse Me with the Facts: Knowledge Claims and Terrorism," Critical Studies on Terrorism 5, no. 1 (April 1, 2012): 47, doi:10.1080/17539153.2012.659908.

${ }^{79}$ Nadia Yusuf, Nisreen Al-Banawi, and Hajjah Abdel Rahman Al-Imam, "The Social Media As Echo Chamber: The Digital Impact," Journal of Business \& Economics Research (JBER) 12, no. 1 (2013): 1-10; Vincent Fella Hendricks, "Is Anyone Immune to the Social Media Echo Chamber?," The Conversation, 2014, http://forskningsbasen.deff.dk/Share.external?sp=S24dee0f2-1ad3-441b-9a47-

a2a963b86be2\&sp=Sku; Lisa Harris and Paul Harrigan, "Social Media in Politics: The Ultimate Voter Engagement Tool or Simply an Echo Chamber," Journal of Political Marketing, 2011, http://eprints.soton.ac.uk/71357/; David Goldie et al., "Using Bibliometric and Social Media Analyses to Explore the 'Echo Chamber' Hypothesis," Educational Policy 28, no. 2 (2014): 281305.

${ }^{80}$ GMA News, "NDF."

${ }^{81}$ For a exhaustive breakdown of the timeline of the Wikileaks cable releases and their relevance to the Philippines see "Interactive Timeline: WikiLeaks Cables and the Philippines," accessed March 7, 2015, http://www.dipity.com/jojomalig/Timeline-WikiLeaks-cables-andthe-Philippines/.

${ }^{82}$ Carlos H Conde, "How the US Really Views the Philippines," Asia Times Online, September 7, 2011, http://www.atimes.com/atimes/Southeast_Asia/MI07Ae01.html.

${ }^{83}$ Jojo Malig, "WikiLeaks Cables: US Forces Directly Involved in Mindanao Terror Hunt," AbscbnNEWS.com, September 14, 2011, http://www.dipity.com/jojomalig/Timeline-WikiLeakscables-and-the-Philippines/.

${ }^{84}$ Collier, "The Philippines' Sanctuaries of Terror." 
${ }^{85}$ East, Terror Truncated: The Decline of the Abu Sayyaf Group from the Crucial Year 2002, xii. ${ }^{86}$ Ibid.

${ }^{87}$ P. N. Abinales and Nathan Gilbert Quimpo, The US and the War on Terror in the Philippines (Anvil, 2008).

${ }^{88}$ Angel Rabasa, Political Islam in Southeast Asia: Moderates, Radicals and Terrorists (Oxford; New York: Oxford University Press for the International Institute for Strategic Studies, 2003), 48.

\section{Bibliography}

Abinales, P. N., and Nathan Gilbert Quimpo. The US and the War on Terror in the Philippines. Anvil, 2008.

Abuza, Zachary. "Funding Terrorism in Southeast Asia: The Financial Network of Al Qaeda and Jemaah Islamiya." Contemporary Southeast Asia: A Journal of International and Strategic Affairs 25, no. 2 (2003): 169-99.

- - - "Tentacles of Terror: Al Qaeda's Southeast Asian Network." Contemporary Southeast Asia 24, no. 3 (December 2002): 427+.

Alipala-Inquirer, Julie, and Cynthia D. Balana. "After Freed Germans, at Least 11 Hostages Still in Abu Sayyaf Hands." Globalnation.inquirer.net, October 19, 2014. http://globalnation.inquirer.net/112923/after-freed-germans-atleast-11-hostages-still-in-abu-sayyaf-hands/.

Banlaoi, Rommel C. "The Abu Sayyaf Group: From Mere Banditry to Genuine Terrorism." Southeast Asian Affairs 2006, no, 1 (2006): 247-62.

Barreveld, Dirk J. Terrorism in the Philippines: The Bloody Trail of Abu Sayyaf, Bin Laden's East Asian Connection. iUniverse, 2001.

Bond, Christopher S. The Next Front: Southeast Asia and the Road to Global Peace with Islam. 1 edition. Chichester: Wiley, 2009.

Bowden, Mark. "Jihadists in Paradise." The Atlantic, March 2007. http://www.theatlantic.com/magazine/archive/2007/03/jihadists-inparadise/305613/.

Brimley, Shawn. "Tentacles of Jihad: Targeting Transnational Support Networks." Parameters 36, no. 2 (June 22, 2006): 30.

Brown, Graham. "The Perils of Terrorism: Chinese Whispers, Kevin Bacon and Al Qaeda in Southeast Asia - A Review Essay." Intelligence and National Security 21, no. 1 (2006): 150-62. doi:10.1080/02684520600568626.

Burnap, Pete, Matthew L. Williams, Luke Sloan, Omer Rana, William Housley, Adam Edwards, Vincent Knight, Rob Procter, and Alex Voss. "Tweeting the Terror: Modelling the Social Media Reaction to the Woolwich Terrorist Attack." Social Network Analysis and Mining 4, no. 1 (December 2014). doi:10.1007/s13278-014-0206-4.

Carlos, Clarita R. "The Links between Organized Crime and Terrorism: The Philippines and the Abu Sayyaf," October 2002.

Chen, Hsinchun, Edna Reid, Joshua Sinai, Andrew Silke, and Boaz Ganor. Terrorism Informatics: Knowledge Management and Data Mining for Homeland Security. Springer Science \& Business Media, 2008. 
Chen, Hsinchun, Yilu Zhou, Edna F. Reid, and Catherine A. Larson. "Introduction to Special Issue on Terrorism Informatics." Information Systems Frontiers 13, no. 1 (January 13, 2011): 1-3. doi:10.1007/s10796-010-9293-6.

Cheong, Marc, and Vincent C. S. Lee. "A Microblogging-Based Approach to Terrorism Informatics: Exploration and Chronicling Civilian Sentiment and Response to Terrorism Events via Twitter." Information Systems Frontiers 13, no. 1 (March 1, 2011): 45-59. doi:10.1007/s10796-010-9273-x.

Collier, Kit. "A Carnival of Crime: The Enigma of the Abu Sayyaf." Conflict, Community, and Criminality in Southeast Asia and Australia, Center for Strategic \& International Studies (CSIS). S, 2009, 44-57.

- - . "Terrorism: Evolving Regional Alliances and State Failure in Mindanao." Southeast Asian Affairs 2006, no. 1 (2006): 26-38.

- - - "The Philippines' Sanctuaries of Terror." Project Syndicate, May 2, 2006. http://www.project-syndicate.org/commentary/the-philippines-sanctuaries-of-terror/english.

Conboy, Kenneth. The Second Front: Inside Asia's Most Dangerous Terrorist Network. Equinox Publishing, 2005.

Conde, Carlos H. "How the US Really Views the Philippines." Asia Times Online, September 7 , 2011. http://www.atimes.com/atimes/Southeast_Asia/MI07Ae01.html.

Connors, Michael K. "War on Error and the Southern Fire: How Terrorism Analysts Get It Wrong." Critical Asian Studies 38, no. 1 (2006): 151-75. doi:10.1080/14672710600556528.

Côté, Isabelle. "Fieldwork in the Era of Social Media: Opportunities and Challenges." PS: Political Science \& Politics 46, no. 03 (2013): 615-19.

Desker, Barry, and Kumar Ramakrishna. "Forging an Indirect Strategy in Southeast Asia." The Washington Quarterly 25, no. 2 (2002): 161-76.

Docena, Herbert. "Philippines: Fanning the Flames of War." Asia Times Online, May 2, 2007.http://www.atimes.com/atimes/Southeast_Asia/IE02Ae03.html.

East, Robert. Terror Truncated: The Decline of the Abu Sayyaf Group from the Crucial Year 2002. Cambridge Scholars Publishing, 2013.

Eklöf, Stefan. Pirates in Paradise: A Modern History of Southeast Asia's Maritime Marauders. NIAS Press, 2006.

Field, Andy. Discovering Statistics Using IBM SPSS Statistics. Sage, 2013. https://books.google.co.uk/books?hl=en\&lr=\&id=c0Wk9IuBmAoC\&oi=fnd \&pg=PP2\&dq=Discovering+Statistics+using +SPSS\&ots=LaBpGMXy1A\&sig= 5yCcX-Szt0mbinlPBT1Dtj2fa8g.

Frake, Charles O. "Abu Sayyaf: Displays of Violence and the Proliferation of Contested Identities among Philippine Muslims." American Anthropologist 100, no. 1 (March 1, 1998): 41-54. doi:10.1525/aa.1998.100.1.41.

Gershman, John. "Is Southeast Asia the Second Front?" Foreign Affairs 81, no. 4 (2002): 60. doi:10.2307/20033240.

GMA News. "NDF: After Clinton Visit, Mindanao May Be next Afghanistan.” GMA News Online, November $\quad 14, \quad 2009$. 
http://www.gmanetwork.com/news/story/176946/news/nation/ndfafter-clinton-visit-mindanao-may-be-next-afghanistan.

Goldie, David, Matthew Linick, Huriya Jabbar, and Christopher Lubienski. "Using Bibliometric and Social Media Analyses to Explore the 'Echo Chamber' Hypothesis." Educational Policy 28, no. 2 (2014): 281-305.

Gonçalves, Pollyanna, Fabrício Benevenuto, and Meeyoung Cha. "PANAS-T: A Pychometric Scale for Measuring Sentiments on Twitter.” arXiv:1308.1857 [physics], August 8, 2013. http://arxiv.org/abs/1308.1857.

Gunaratna, Rohan. Inside Al Qaeda : Global Network of Terror. Reissue., 2003.

Gutierrez, Eric. "From Ilaga to Abu Sayyaf: New Entrepreneurs in Violence and Their Impact on Local Politics in Mindanao." Philippine Political Science Journal 24, no. 47 (December 1, 2003): 145-78. doi:10.1080/01154451.2003.9754250.

Hamilton-Hart, Natasha. "Terrorism in Southeast Asia: Expert Analysis, Myopia and Fantasy." The Pacific Review 18, no. 3 (2005): 303-25. doi:10.1080/09512740500188845.

Harris, Lisa, and Paul Harrigan. "Social Media in Politics: The Ultimate Voter Engagement Tool or Simply an Echo Chamber." Journal of Political Marketing, 2011. http://eprints.soton.ac.uk/71357/.

Hendricks, Vincent Fella. "Is Anyone Immune to the Social Media Echo Chamber?" The Conversation, 2014. http://forskningsbasen.deff.dk/Share.external?sp=S24dee0f2-1ad3-441b9a47-a2a963b86be2\&sp=Sku.

Hoskins, Andrew, and Ben O'Loughlin. War and Media. Polity Press, 2010.

Hutchinson, Steven, and Pat O'malley. "A Crime-Terror Nexus? Thinking on Some of the Links between Terrorism and Criminality." Studies in Conflict \& Terrorism 30, no. 12 (2007): 1095-1107. doi:10.1080/10576100701670870.

"Interactive Timeline: WikiLeaks Cables and the Philippines." Accessed March 7, 2015. http://www.dipity.com/jojomalig/Timeline-WikiLeaks-cables-andthe-Philippines/.

James, Michael S., and and John K. Cooley. "The Abu Sayyaf-Al Qaeda Connection.” ABC News, January 6, 2006. http://abcnews.go.com/International/story?id=79205\&page $=1$.

Jenkins, Philip. Images of Terror: What We Can and Can't Know about Terrorism. New York: Aldine de Gruyter, 2003.

Jones, David Martin, M. L. R. Smith, and Mark Weeding. "Looking for the Pattern: Al Qaeda in Southeast Asia-The Genealogy of a Terror Network." Studies in Conflict \& Terrorism 26, no. 6 (2003): 443-57. doi:10.1080/10576100390248284.

Joscelyn, Thomas. "Global Al Qaeda: Affiliates, Objectives, and Future Challenges." The Long War Journal 18 (2013). http://defenddemocracy.org/content/uploads/documents/TJFormattedTe stimony7_18.pdf. 
Juris, Jeffrey S. "Reflections On\# Occupy Everywhere: Social Media, Public Space, and Emerging Logics of Aggregation." American Ethnologist 39, no. 2 (2012): 259-79.

Kingsbury, Damien. Violence in between: Conflict and Security in Archipelagic Southeast Asia. Clayton; Singapore: Monash Asia Institute; Institute of Southeast Asian Studies, 2005.

Lee-Brago, Pia. "Mindanao Could Be next Afghanistan - US Diplomat." Philstar.com, April 11, 2005. http://www.philstar.com/headlines/273463/mindanaocould-be-next-afghanistan-- -us-diplomat.

Liow, Joseph Chinyong. "International Jihad and Muslim Radicalism in Thailand?: Toward an Alternative Interpretation." Asia Policy 2, no. 1 (2006): 89-108.

_-_. "ISIS Goes to Asia." Foreign Affairs, September 19, 2014. http://www.foreignaffairs.com/articles/142004/joseph-chinyongliow/isis-goes-to-asia.

Malig, Jojo. "WikiLeaks Cables: US Forces Directly Involved in Mindanao Terror Hunt." Abs-cbnNEWS.com, September 14, 2011. http://www.dipity.com/jojomalig/Timeline-WikiLeaks-cables-and-thePhilippines/.

Markham, Annette. "Fieldwork in Social Media: What Would Malinowski Do?" Qualitative Communication Research 2, no. 4 (2013): 434-46.

Monroy-Hernández, Andrés, danah boyd, Emre Kiciman, Munmun De Choudhury, and Scott Counts. "The New War Correspondents: The Rise of Civic Media Curation in Urban Warfare." In Proceedings of the 2013 Conference on Computer Supported Cooperative Work, 1443-52. CSCW '13. New York, NY, USA: ACM, 2013. doi:10.1145/2441776.2441938.

O'Brien, McKenzie. "Fluctuations Between Crime and Terror: The Case of Abu Sayyaf\&\#039;s Kidnapping Activities." Terrorism and Political Violence 24, no. 2 (2012): 320-36. doi:10.1080/09546553.2011.648679.

Oh, Onook, Manish Agrawal, and H. Raghav Rao. "Information Control and Terrorism: Tracking the Mumbai Terrorist Attack through Twitter." Information Systems Frontiers 13, no. 1 (September 25, 2010): 33-43. doi:10.1007/s10796-010-9275-8.

Peng, Chao-Ying Joanne, and Tak-Shing Harry So. "Logistic Regression Analysis and Reporting: A Primer." Understanding Statistics: Statistical Issues in Psychology, Education, and the Social Sciences 1, no. 1 (2002): 31-70.

Perliger, Arie, and Ami Pedahzur. "Social Network Analysis in the Study of Terrorism and Political Violence." PS: Political Science \& Politics 44, no. 01 (January 2011): 45-50. doi:10.1017/S1049096510001848.

Rabasa, Angel. Political Islam in Southeast Asia: Moderates, Radicals and Terrorists. Oxford; New York: Oxford University Press for the International Institute for Strategic Studies, 2003.

Ramakrishna, Kumar. "Countering Radical Islam in Southeast Asia: The Need to Confront the Functional and Ideological 'enabling Environment."' In Terrorism and Violence in Southeast Asia: Transnational Challenges to States 
and Regional Stability, edited by Paul J. Smith, 145-68. East Gate Books, 2005.

Reinares, Fernando. "Radicalisation Processes Leading to Acts of Terrorism." European Commission's Expert Group on Violent Radicalisation, 2008. http://www.clingendael.nl/sites/default/files/20080500_cscp_report_vries .pdf.

Ressa, Maria. From Bin Laden to Facebook 10 Days of Abduction, 10 Years of Terrorism. Hackensack, NJ: World Scientific Pub. Co., 2013. http://search.ebscohost.com/login.aspx?direct=true\&scope=site\&db=nlebk $\& \mathrm{db}=$ nlabk\&AN $=575392$.

- - - Seeds of Terror: An Eyewitness Account of Al-Qaeda's Newest Center. Free Press, 2011.

Rollins, John. Al Qaeda and Affiliates: Historical Perspective, Global Presence, and Implications for U. S. Policy. DIANE Publishing, 2010.

Ronfeldt, David. "Al Qaeda and Its Affiliates: A Global Tribe Waging Segmental Warfare?" First Monday 10, no. 3 (March 7, 2005). doi:10.5210/fm.v10i3.1214.

Rosario, Ambassador Albert del. "A Progress Report on the Philippines." The Heritage Foundation, March 2002. http://www.heritage.org/research/lecture/a-progress-report-on-thephilippines.

Shi, Wei, Hongwei Wang, and Shaoyi He. "Sentiment Analysis of Chinese Microblogging Based on Sentiment Ontology: A Case Study of '7.23 Wenzhou Train Collision.'” Connection Science 25, no. 4 (December 1, 2013): 161-78. doi:10.1080/09540091.2013.851172.

Singh, Bilveer. The Talibanization of Southeast Asia: Losing the War on Terror to Islamist Extremists. New Delhi: Praeger, 2007.

Stohl, Michael. "Don't Confuse Me with the Facts: Knowledge Claims and Terrorism." Critical Studies on Terrorism 5, no. 1 (April 1, 2012): 31-49. doi:10.1080/17539153.2012.659908.

Tabachnick, Barbara G., and Linda S. Fidell. Using Multivariate Statistics. 5 edition. Boston: Pearson, 2006.

Tan, Andrew. Security Strategies in the Asia-Pacific: The United States' "Second Front" in Southeast Asia. New York: Palgrave Macmillan, 2011.

- - - "Southeast Asia as the 'second Front' in the War against Terrorism: Evaluating the Threat and Responses." Terrorism and Political Violence 15, no. 2 (2003): 112-38. doi:10.1080/09546550312331293067.

Tan, Andrew, and Kumar Ramakrishna. The New Terrorism: Anatomy, Trends, and Counter-Strategies. Eastern Universities Press, 2002.

Thayer, Carlyle Alan. "Al-Qaeda and Political Terrorism in Southeast Asia." In Terrorism and Violence in Southeast Asia: Transnational Challenges to States and Regional Stability, by Paul J. Smith, 2005.

Thayer, Carlyle Alan, and Greg Fealy. "Problematising 'linkages' between Southeast Asian and International Terrorism." In Security Politics in the Asia-Pacific: A 
Regional-Global Nexus?, edited by William T. Tow. Cambridge University Press, 2009.

Thelwall, Mike, Kevan Buckley, and Georgios Paltoglou. "Sentiment in Twitter Events." Journal of the American Society for Information Science and Technology 62, no. 2 (2011): 406-18.

Thurman, Neil. "Forums for Citizen Journalists? Adoption of User Generated Content Initiatives by Online News Media." New Media \& Society 10, no. 1 (2008): 139-57.

Ugarte, Eduardo F. "In a Wilderness of Mirrors': The Use and Abuse of the 'Abu Sayyaf Label in the Philippines." South East Asia Research 18, no. 3 (September 1, 2010): 373-413. doi:10.5367/sear.2010.0002.

- - - "The Phenomenon of Kidnapping in the Southern Philippines: An Overview." South East Asia Research 16, no. 3 (November 1, 2008): 293341.

Ugarte, Eduardo F., and Mark Macdonald Turner. "What Is the 'Abu Sayyaf'? How Labels Shape Reality." Pacific Review 24, no. 4 (2011): 397-420. doi:10.1080/09512748.2011.596558.

Van Dijck, José. "Users like You? Theorizing Agency in User-Generated Content." Media, Culture, and Society 31, no. 1 (2009): 41.

Vellema, Sietze, Jr, Saturnino M. Borras, and Jr, Francisco Lara. "The Agrarian Roots of Contemporary Violent Conflict in Mindanao, Southern Philippines." Journal of Agrarian Change 11, no. 3 (July 2011): 298-320. doi:10.1111/j.1471-0366.2011.00311.x.

Woon, Chih Yuan. "For 'emotional Fieldwork' in Critical Geopolitical Research on Violence and Terrorism." Political Geography 33 (March 2013): 31-41. doi:10.1016/j.polgeo.2012.11.007.

- - - "Undoing Violence, Unbounding Precarity: Beyond the Frames of Terror in the Philippines." Geoforum 42, no. 3 (June 2011): 285-96. doi:10.1016/j.geoforum.2011.04.003.

Yusuf, Nadia, Nisreen Al-Banawi, and Hajjah Abdel Rahman Al-Imam. "The Social Media As Echo Chamber: The Digital Impact." Journal of Business \& Economics Research (JBER) 12, no. 1 (2013): 1-10. 